\title{
La literatura histórica \\ en Costa Rica hoy: contribución al debate teórico
}

\section{Albino Chacón}

Universidad Nacional, Costa Rica

La relación entre las producciones discursivas histórica y literaria es de siempre, e incluso ha habido períodos en los que no ha existido una distinción entre ellas. Uno podría pensar que a lo mejor ello se debe a que ambas han cumplido funciones que van mucho más allá de lo que sería una simple complementariedad, y que tienen que ver con la elaboración, la síntesis, por parte de ambas producciones, de aquello que constituye el imaginario nacional, simbólico, que una cultura crea de sí y para sí misma y la constituye en sus rasgos definitorios. Esa es, a mi entender, una de las funciones básicas que emparienta a la literatura y a la historia: la de contar, volver a contar, construir y desconstruir, armar y rearmar, como un rompecabezas al que ineluctablemente por cierto siempre le faltan piezas, las narrativas que conforman la historia de una sociedad y las imágenes que sus habitantes han construido de sí mismos. Como plantea Paul Ricoeur, podemos entender la literatura y la historia como subgéneros de estructuras narrativas comunes, y en ese intercambio entre historia y ficción y entre sus pretensiones referenciales opuestas, nuestra historicidad es llevada al lenguaje. Por eso nos es tan fácil leer la historia como literatura y la literatura como historia, porque más que de marcas discursivas intrínsecas que las diferencien, pareciera tratarse sobre todo de un asunto de clasificación, de circulación y de recepción. 
A todos nos va resultando en la vida cada vez menos claro qué tipo de discurso fue el que estuvo en el origen de lo que llegamos a considerar un conocimiento cierto y distinto sobre un aspecto de la realidad social o de la historia. Pocas veces somos capaces de discernir claramente por qué sobre un asunto pensamos como pensamos. Los orígenes tienden a perderse, a confundirse, y al final ya no sabemos si aquello que reproducimos de buena fe en nuestros propios discursos, y por lo que pasaríamos perfectamente la prueba del detector de mentiras, lo hemos conocido porque nos lo contaron en una vela, lo leímos en Selecciones, lo vimos en un filme, o si lo leímos en un libro confiable, es decir, en un libro de historia, o en un libro menos confiable, de esos que en el siglo Xvi Carlos V calificaba de «fábulas vanas [...] de mentirosas ystorias», esto es, en la literatura, en las novelas.

Hasta no hace mucho, la narrativa literaria reivindicaba el carácter ficcional como uno de sus rasgos definitorios, entre otros se entiende, pero éste de manera particular. La literatura como artefacto de invención de historias autosuficientes, de manera particular en el llamado período del boom, marcado por una fuerte experimentación lingüística y en las estructuras narrativas. Contrariamente, hoy asistimos a una práctica literaria que efectúa, de manera notable, un acercamiento intencional, explícito a las fuentes documentales históricas y al género histórico como estrategia narrativa. Esto es claro en la literatura latinoamericana en general; ahí tenemos los nombres de Mario Vargas Llosa, Augusto Roa Bastos, Elena Poniatovska, Carlos Fuentes, Marco Antonio Flores o Monteforte Toledo. O la eclosión de todo un género, el testimonio, volcado a escribir y a interpretar la historia reciente de hechos que apenas ayer ocurrieron.

Mencioné antes lo que en la distinción genérica historia-literatura tiene que ver el asunto de la recepción de los textos. Pues bien, ¿quién no lee un testimonio o una novela testimonial como si en verdad se tratara de un libro que nos informa - como dirían los abogadossobre la verdad real de los hechos? El alto grado de referencialidad y 
la cercanía temporal de los acontecimientos que se narran en el género testimonial son dos de los factores que han causado, a mi entender, que se ponga en duda su carácter literario: el testimonio es un género narrativo molesto, por inclasificable. Por otra parte, rara vez trabaja con fuentes documentales; en general elabora exclusivamente a partir de la memoria viva de los protagonistas, y esto de alguna manera lo saca del prestigio de la esfera letrada y lo relaciona más, por su origen, con la esfera de la oralidad. A pesar de que el resultado final circula mediante libros, la cultura oficial, sus instituciones y portavoces se portan muy a menudo realmente implacables cuando se trata de juzgar el testimonio como perteneciente al hecho literario.

Llamo la atención sobre el testimonio, sin pretender detenerme más, porque aun cuando de manera incuestionable forma parte del gran conjunto de la narrativa histórica, tiende a quedar por fuera cuando se debate alrededor del tema de literatura e historia, y porque en el presente también comienza a escribirse en Costa Rica, si bien con características distintas al testimonio que se ha venido escribiendo en los otros países del norte de Centroamérica.

Lo que estrictamente llamamos novela histórica, la que se escribe hoy, a diferencia del origen oral del testimonio, se elabora sobre una base documental escrita que, por lo demás, ella no pretende ocultar y con la que establece una referencialidad textual. Se trata, bien vemos, de un proceso de mímesis, pero - y esta es su característica fundamental-que no sigue las mismas intenciones estéticas y procedimientos de la novela histórica del siglo xIx y de la primera mitad del siglo xx. Trabaja con procedimientos de síntesis y de «flagrante» reelaboración documental, de citas textuales o presuntamente textuales. Se trata de mímesis de textos históricos, no de mímesis de lo real, y tiene como efecto el provocar nuevo conocimiento que se enf renta, e incluso compite, con el conocimiento histórico positivo. Se trata de una literatura que se desborda a sí misma y, al merodear impunemente en una credibilidad que parecía exclusiva de la narrativa histórica, ha terminado redefiniendo el campo de lo ficcional. Si la relación 
literatura-ficción parecía ser una conexión, una correspondencia inapelable, hoy una buena cantidad de textos que se están escribiendo dentro de la esfera literaria hacen expresa su naturaleza documental.

Veamos de manera particular la novela Cundila, del historiador y ahora también novelista Iván Molina, que no calificaría como una novela histórica en estricto sentido, si por ello entendemos que debe haber una correspondencia reconocible entre acontecimientos y protagonistas del texto novelesco y sus correspondientes históricos, pero sí lo sería por otras razones. Este nadar entre dos aguas es lo que me parece interesante en la novela de Iván. Por su concepción y trama se emparienta claramente con El nombre de la rosa, de Umberto Eco. Recordemos brevemente que la peripecia principal en Cundila es la búsqueda detectivesca por parte del protagonista, el profesor de literatura Froylán Figueroa, de una presunta segunda parte de El moto, de Joaquín García Monge, escrita poruna mujer, Olga Turcios, y sobre cuya existencia el protagonista habría encontrado referencias en el Índice bibliográfico de Costa Rica, de Luis Dobles Segreda, en una visita de trabajo a la Biblioteca del Congreso de los Estados Unidos. Al igual que la segunda parte de la Poética de Aristóteles, esta segunda parte de El moto termina destruida y se pierde para siempre, pero ya no por un incendio provocado por algún monje ciego, sino por los antimotines de la policía costarricense, al arremeter contra la persona que tenía el documento en su bolso durante una manifestación contra la privatización del ICE, en los alrededores de la Fuente de la Hispanidad. Reciclaje de una anécdota, territorialización local, juego mimético con otro texto literario, todos elementos que abonan el carácter ficcional novelescamente posmoderno de Cundila. Y sin embargo, a la hora de dar los créditos al final, Iván indica al lector que "los personajes, experiencias, instituciones y eventos descritos en este libro son ficticios o utilizados ficticiamente, y cualquier parecido con personas, situaciones y acontecimientos reales es pura coincidencia". Por supuesto, en lo que uno entra de inmediato en sospecha es por qué un escritor de una novela de ficción, inmediatamente acabada la 
escritura, siente la necesidad de hacer semejante aclaración, que uno tendería más bien a interpretar como una confesión. Lo que está en el origen de la necesidad de hacer semejante aclaración, y que a nosotros nos interesa resaltar es, justamente, la alta referencialidad contextual, histórica, que un texto como Cundila puede alcanzar, a pesar de la ficcionalidad de la trama, mediante la creación de ambientes, lugares y hechos verificables que sirven de marco a una anécdota que, además, se monta sobre la base de un texto real como es El moto.

Como historiador, Iván Molina conoce esos peligros, esto es, la textura literaria que tiene el discurso histórico, pero también la textura histórica que puede alcanzar el texto literario. Cundila, entonces, se mueve en el terreno móvil, inclasificable, discursivamente ubicuo en que se mueve la novela histórica, sobre todo cuando ya no vemos ésta como una cuestión de temas y de anécdotas verificables empíricamente, sino los mecanismos y estrategias textuales que pone en juego y el tipo de recepción y lectura veredictiva que es capaz de desencadenar, así como por la alta densidad de su entorno referencial, éste sí empíricamente verificable. En su nota final Iván reivindica el carácter ficcional del texto, pero inmediatamente pasa a ofrecernos, tal como se estila en las novelas históricas, una lista comentada de las fuentes documentales y los autores que le sirvieron de base para la recreación de datos y ambientes en la novela. Si el testimonio se impone como meta la credibilidad sobre la base de la experiencia y de la memoria confiable del protagonista, y de ahí extrae su verdad, la novela histórica extrae su verdad de una manera doble: por una parte, de la base documental de que se sirve; por otra, del conocimiento que de la versión oficial tiene ya de manera general el lector y que forma parte de la doxa, es decir, de un preconstruido social.

Frente al texto histórico, que tiene por supuesto su propia retórica argumental, la novela histórica presenta un trabajo de artificiosidad en la reinvención, esto es, un trabajo ficcional que apuntala la credibilidad referencial a partir de la verosimilitud de los elementos ficcionales. Referencialidad y verosimilitud son los términos claves. 
Contrario a lo que sucede en muchos otros textos literarios, no se trata en la novela histórica de poner elementos históricos al servicio del verosímil ficcional sino, curiosamente, al contrario: se pone el verosímil ficcional al servicio de la referencialidad histórica.

Lo anterior me parece definitorio para entender la economía narrativa que rige a la novela histórica. Uno podría plantearse, y me parece que con bastante legitimidad, si la novela no se convierte, dentro de este esquema, en una nueva manera de hacer historia, si no se cumple en ella el ideal de unir los dos géneros narrativos por excelencia - historia y literatura - sin que la ficción de esta última resulte una incomodidad, un descrédito, una sospecha, sino simplemente un cuerpo de procedimientos y estrategias, es decir, una tecnología discursiva. Parece, en todo caso, dado el éxito de la novela histórica, que el mundo está a gusto con esta tecnología: los escritores literarios, los historiadores, los lectores en general, que ya no sienten que leen solo «fábulas vanas [...] de mentirosas ystorias», sino que al leer una novela están leyendo algo más que una trama interesante, no importa en qué estante el librero haya ubicado el libro. Al final, como pareciera desprenderse de las declaraciones de tantos autores literarios, lo que hacen éstos no es sino pedir prestada a la realidad un poco de la inmensa ficción que ya de por sí hay en ella, y deben tomar solo un poco porque, si no, su novela podría no resultar creíble, como lo dice Alfonso Chase en El pavo real y la mariposa, al of recer la lista de documentos que le sirvieron de base, o como también lo plantea Anacristina Rossi en Limón blues.

Un caso paradigmático en este orden de cosas de literatura, historia y ficción que nos ocupa, es precisamente el de la última novela mencionada, Limón blues, de Anacristina Rossi, quien of rece al final una lista de los libros, artículos de periódico, de revista, cartas y documentos de archivo que le permitieron elaborar, capítulo por capítulo, el mundo, los ambientes, las costumbres, el perfil de los protagonistas esenciales y, en general, la pintura del Limón de las primeras décadas del siglo xx. Las referencias documentales son muy minuciosas, con lo 
que Rossi pareciera querer decirnos, "nada de esto lo he inventado yo"; lo cierto es que lo que ahí se cuenta solo podía hacerse desde la literatura, un texto histórico no habría podido hacerlo. Para ello, Rossi realiza primero un trabajo de lectura y de hermenéutica de la información acumulada, para luego volcar su interpretación en la recreación de la cotidianidad de ese mundo en el texto novelesco. En un artículo escrito en 1942, el ilustre historiador de la literatura y de la cultura panameña, Rodrigo Miró, afirmaba una función de la literatura frente a la historia que, ubicada en el contexto de la época, merece ser recordada. Escribió Miró que: "lo que suele llamarse la Historia registra hechos parciales, generalmente hechos de la política y de la administración del Estado. En cambio, del alma misma de cada país, de lo que en determinado instante piensan y sienten y anhelan sus habitantes, de la manera como ríen y hablan, de como visten y se hacen el amor [...] eso nos lo cuenta la literatura". Y agregaba: "Su estudio [el de la literatura] ha de ser, tanto como pasatiempo agradable, ejercicio necesario, tarea que conviene emprender con claridad de miras, como garantía de autoconocimiento, como política de introspección y de afirmación nacional". De ahí Miró extrae una conclusión de altas miras políticas en ese momento, y que hoy resulta de una actualidad asombrosa. Concluía Miró: "Hemos llegado a una etapa de nuestro desenvolvimiento en que parece cerrarse todo un ciclo histórico. Ese hecho, y las exigencias de la hora trágica que vive el mundo, aconsejan un severo examen de conciencia [...]. Acaso la primera gestión de alto vuelo nos la depare la inaplazable necesidad de conocernos, de saber quiénes somos, cuál es nuestro origen y cómo nos hemos constituido en nación".

Como se habrá notado, para referirme a la producción que ha sido objeto de esta exposición, he utilizado de manera totalmente intencional la denominación de novela histórica, para diferenciarla de la así llamada nueva novela histórica. Ciertamente, no se trata de lo mismo, en la medida en que esta "nueva novela histórica" echa mano a procedimientos tales como la distorsión, las exageraciones, los 
anacronismos, lo que da por resultado una parodización, cuando no una caricaturización, de la historia, y de manera particular de los movimientos políticos de izquierda de la historia reciente centroamericana. Habría que dilucidar con cuidado las razones editoriales, políticas, sociales de esto último. Lo que hoy se produce como novela histórica o como nueva novela histórica conforman campos diversos, con propuestas estéticas que resultan radicalmente distintas, incluso opuestas, que desde mi punto de vista nacen de perspectivas políticas y culturales diferentes.

De aquí podemos interpretar, en lo que corresponde estrictamente a Costa Rica, el gesto que en los órdenes literario, cultural, histórico, pero también en el político, cumple la novela histórica de escritores como Anacristina Rossi, Tatiana Lobo, o en esta misma línea textos publicados por Quince Duncan, Gerardo César Hurtado o Fernando Durán Ayanegui, para citar solo algunos. Se trata de esfuerzos sostenidos por reescribir nuestra historia, por pasar revista a sujetos marginalizados, por revisitar períodos y acontecimientos, o el reelaborar personajes consagrados por una historia oficial con la que, ciertamente, estos escritores no estaban o no están satisfechos. En esa voluntad de reescritura hay una productiva complicidad entre historia y literatura, pero al mismo tiempo una violencia, una especie de palimpsesto: al sobreescribir sobre el texto histórico, la literatura boronea, produce tachones, intercala, abre intersticios, y con ello busca modificar ideas hechas, imágenes de lo nacional que dieron como resultado una centralidad identitaria monológica que ha caracterizado mucho la historia nacional. Dicho de otro modo, en la relación dialógica que hay en su trabajo, el escritor revela la deuda, la relación filial de su trabajo hacia el documento histórico, pero no para afirmar al Padre, la gran Historia, como hizo de manera general la novela histórica de la primera mitad del siglo $\mathrm{xx}$, cuando funcionó como representación literaria preconstruida en el discurso histórico y, por tanto, como reproductora de las mismas matrices discursivas e ideológicas. Contrario a esto, y en un gesto que tiene mucho de negación, 
la novela histórica que hoy se escribe en Costa Rica no reproduce, sino que reescribe. La novela histórica contemporánea, a diferencia de su antecesora, no es una literatura de afirmación sino de crisis. De crisis de modelos y de preconstruidos, no así del concepto básico de construcción histórica de la nacionalidad. En el momento actual, o como diría Miró, "en esta hora trágica que vive el mundo", es fundamental tener eso presente. 